\title{
JUAN LUIS VIVES Y LA RESPONSABILIDAD PARA CON LOS POBRES
}

\author{
JOSÉ MANUEL PANEA MÁRQUEZ \\ Universidad de Sevilla
}

\begin{abstract}
RESUMEN: Juan Luis Vives (Valencia 1492, Brujas 1540) reflexionó sobre el tema de la pobreza como un problema de justicia personal y social. El abandono en el que vivían los pobres, cuyo número iba en aumento en pleno siglo XVI, plantea no sólo problemas de orden social, sino también moral y religioso. Reflexionar sobre dicho asunto le ofrece a Vives la oportunidad para realizar una fuerte crítica, no sólo de aquellos que detentan el poder político y religioso, sino también para exigir un cambio de actitud, en el plano individual e institucional, y una reflexión sobre la propia esencia del cristianismo. Por todo ello, Vives ofrece no sólo un conjunto de medidas concretas para tratar de afrontar dicho problema, sino también un amplio abanico de razones morales y religiosas, con las que será muy difícil poder negar nuestra responsabilidad para con los pobres, a la vez que nos exhorta a que hagamos frente común contra la pobreza.
\end{abstract}

PALABRAS CLAVE: J. L. Vives; pobreza; justicia; cristianismo; responsabilidad moral; razones morales; políticas y religiosas.

\section{Juan Luis Vives and the responsibility towards the poor}

ABSTRACT: Juan Luis Vives (Valencia 1492, Bruges 1540) reflected upon the matter of poverty as a problem of personal and social justice. As the number of poor was increasing all through the 16th century, their abandonment laid out not only social order problems, but also moral and religious ones. The fact of reflecting upon such a matter provides Vives with the opportunity to fulfill a strong criticism of those who hold the political and religious power, as well as to demand a change in the attitude, at an individual and institutional level, and a reflection on the own essence of Christianity. Therefore, Vives offers both a set of specific measures to try to face such a problem and a wide range of moral and religious reasons so as to complicate the possibility of refusing our responsibility towards the poor, while the author exhorts us to face poverty together.

KEY WORDS: J. L. Vives; poverty; justice; christianity; moral responsibility; moral; political and religious reasons.

«En el Deuteronomio habla así el Señor: No faltarán pobres en la tierra de tu morada, por eso te mando que abras tu mano al necesitado y al pobre, que vive contigo en la tierra» ${ }^{1}$.

1 Luis Vives, De subventione pauperum, Libro I, capítulo X. Todas las citas de J. L. Vives tienen como base la edición digital de sus Obras completas, a cargo de la Biblioteca Valenciana Digital. Francisco Calero, editor y traductor del De subventione pauperum. Sive de humanis necessitatibus. Libri I-II, aclara en nota que toma como referencia la edición crítica de C. Matheeusen y C. Fantazzi, y también las notas de Juan Moyard de su segunda edición. Desde ahora nos referiremos a ella como $D s p$. 
Lamentablemente, la cita del Deuteronomio, que le sirve a Vives para exigir una respuesta al problema de la pobreza, sigue teniendo plena actualidad. Los pobres están ahí, y seguirán estando, y no de modo circunstancial. Así que, como cristiano y como hombre, trata de argumentar la exigencia moral y política para dar una respuesta a dicho problema. Y aunque medien algunos siglos, y las circunstancias que en cada momento originan la pobreza puedan ser bien distintas, sin embargo, el hecho al que nos enfrentamos es el mismo. Hoy miles de seres humanos huyen de las guerras, buscando asilo, protección y un futuro para los suyos. El debate sobre dicha problemática ha saltado a la esfera pública. Abandonan sus casas, y en su huida, nuevamente, los pobres se encontrarán con quienes querrán abrirles las puertas y acogerlos, pero también con quienes levantarán muros y alambradas para despedirlos ${ }^{2}$.

Sin duda, somos conscientes de la magnitud y la complejidad del problema hoy, que requerirá de decisiones técnicas precisas. No obstante, detrás de las soluciones están las actitudes que las inspiran, porque sabemos que de ellas depende, en gran medida, el modo de afrontar dichas respuestas. En tal sentido, la aportación de Vives nos parece fundamental, en tanto que con sus razones nos permite ensanchar nuestra visión del problema, y nos brinda la oportunidad de ejercer una lúcida autocrítica.

No deja de ser sorpredente que Juan Luis Vives, (Valencia 1492, Brujas 1540) se ocupara de los marginados, de los que viven en las márgenes de todo, y, por ende, también de los olvidados del pensamiento. Y lo hace, fundamentalmente, en $D e$ subvenione pauperum, que, junto a De communione rerum, expresa su pensamiento social. Sin lugar a dudas, la obra de Vives, que abrió un debate continuado por otros intelectuales de su tiempo de innegable talla ${ }^{3}$, ha contribuido notablemente a conformar ese estrato filosófico del que germinará, siglos depués, la idea de los derechos humanos, y sobre la que el cristianismo tanto ha influido ${ }^{4}$.

2 Como muy bien ha escrito Óscar A. Rodríguez Madariaga: «La sociedad deshumaniza en la medida en que se mercantiliza. Las fronteras tienden a estar indiscriminadamente abiertas para los bienes y cerradas para las personas. La falta de desarrollo de muchos países produce un éxodo incontrolable de refugiados económicos que está llevando al mundo desarrollado a encerrarse tras muros físicos o raciales». Rodríguez Madariaga, O., Sin ética no hay desarrollo, Madrid, Narcea, 2014, p. 23.

3 Entre los que cabe citar, que se ocuparían en lo sucesivo, del tema social de la pobreza, están Domingo de Soto, Juan de Robles, Lorenzo de Villavicencio, Martín de Azpilicueta, Miguel de Giginta, Cristóbal Pérez de Herrera y Pedro de Valencia. Cfr. J. De LA Iglesia, J., «El debate sobre el tratamiento de los pobres en el siglo XVI», en CAmpos y Fernández de SeVILla, F. J., (coord.), La iglesia española y las instituciones de caridad. Real Centro Universitario Escorial-María Cristina. Ediciones Escurialenses, pp. 5-30, 2006. Un estudio muy detallado del contexto social, político y económico puede encontrarse en LóPEZ DE GoICOCHEA, ZABALA, J., «De subventione pauperum: los tratados sobre la pobreza en los orígenes del Estado Moderno», en Revista de estudios jurídicos, económicos y sociales, vol. I, Universidad Alfonso X el Sabio, Villanueva de la Cañada, 2003, para quien la obra de Vives fue el detonante que disparó el conjunto de reflexiones y discusiones que le siguieron después, como la que protagonizaron Soto y Juan de Robles.

4 No en vano J. Habermas ha llamado la atención al respecto, al destacar la importancia de la escolástica española, y muy particularmente, de Francisco Suárez, para la teoría de los derechos humanos. Cfr. HABERMAS, J., «El resurgimiento de la religión, ¿un reto para la autocomprensión de la modernidad?», Dianoia 60, LIII, 2008. Nos hemos ocupado de la importancia de la religión en J. Habermas en PaneA, J. M.,"Sobre el debate Habermas/ Flores D'Arcais en torno al papel de la religión en la esfera pública”, en Pensamiento, vol. 69, 2013, n² 261, pp. 1019-1033. 
Como decíamos, el debate sobre la pobreza, tanto ayer como hoy, suscita polémica. El propio Vives, que había redactado De subventione pauperum entre mayo de 1525 y enero de 1526, recién publicado se encontró ya con la resistencia del obispo de Sarepta 5 . Sin embargo, lo que nos interesa destacar ahora es la actitud de Vives ante el problema. Lo que está detrás de sus reflexiones y de su crítica es la indignación ante el lacerante hecho de la pobreza, que cada vez afectaba a más personas en aquella Europa en crisis de principios del XVI ${ }^{6}$. Y lo que Vives pretenderá es que los pobres encuentren remedio para la situación de total abandono, tanto individual como institucional, que estaban padeciendo.

De aquí que escriba la obra y la dedique, nada más ni nada menos, que a los burgomaestres y al Consejo municipal de Brujas. Para Vives, y aquí estará la originalidad y firmeza de su planteamiento, el problema de la pobreza no puede seguir quedando en el plano de la charitas individual. Tal problemática exigiría, además, una respuesta institucional. Una cuestión tan importante para las personas, como es la de hacer frente a las condiciones objetivas de su pobreza, no puede quedar a merced de las contingencias de la buena voluntad, y del alcance de la caridad individual, sino que exige la continuidad de una respuesta institucional, cuyo núcleo primero de actuación serán los propios municipios. Pero Vives irá más allá de la esfera política, y en tanto cristiano, no dejará pasar la oportunidad para ejercer también, al hilo de nuestro tema, una revisión crítica del propio cristianismo, tal y como la venía desarrollando en otro sentido ${ }^{7}$. Por eso, Bataillón nos recuerda que Vives escribe a Cranevelt diciendo que ha tomado muchas precauciones, refiriéndose a que tuvo mucho cuidado de no mezclar el problema de la mendacidad en general con el de la mendacidad de las órdenes mendicantes ${ }^{8}$. Pero, por otra parte, y como muy bien ha destacado F. Calero, no podemos pasar por alto la valentía de Vives al sostener, abiertamente, que los bienes de los obispos y de los sacerdotes pertenecían en su origen a los pobres, y que con sus riquezas bastaría, en gran medida, para solucionar las necesidades de los indigentes ${ }^{9}$.

Sin embargo, aunque muchas de sus críticas vayan dirigidos al clero, y sirvan para replantearse el papel de la Iglesia y de los cristianos ante dicha problemática, lo que le mueve realmente a escribir sobre dicho tema es la indignación que le provoca el lacerante contraste entre la opulencia y la pobreza. Por ello, aunque sus dardos, en ocasiones, vayan dirigidas contra integrantes de la jerarquía de la Iglesia, no deberíamos perder de vista que lo que le solivianta no son los

5 Cfr. Bataillon, M., Erasmo y el erasmismo, Barcelona, Crítica, 1977, p. 182.

6 Para este tema, y en concreto sobre las cifras de la pobreza en Europa, debido a las malas cosechas, hambrunas, enfermedades y guerras, cfr. Geremer, B., La piedad y la Horca. Historia de la miseria y de la caridad en Europa. Madrid, Alianza, 1998, cap. 3.

7 Compartimos la tesis sostenida por M.A. Coronel al afirmar que Vives es un reformador de la Iglesia, si bien su excelente trabajo no se centra en la problemática de la pobreza, sino en la discusión, por parte de Vives, de un cristianismo más auténtico, más cercano al espíritu del Evangelio, y más distante de la dogmática, todo lo cual concuerda, a nuestro parecer, con el enfoque que da Vives al problema de los pobres. Cfr. Coronel Ramos, M. A., «Algunas reflexiones sobre Juan Luis Vives como reformador de la Iglesia», en Studia Philologica Valentina, Vol. 14, n.s. 11, (2012) 203-215.

8 Cfr. Bataillon, M., op. cit., p. 183.

9 Cfr. CAlero, F., Introducción a Dsp, «El pensamiento social de Luis Vives», p. 15. 
protagonistas concretos, sino la situación de injusticia extrema que padecen los pobres, y el contraste con los que gozan de una vida regalada, queja que podemos hacer perfectamente extrapolable hoy, en pleno siglo XXI, ante el escándalo de la pobreza.

Por otra parte, y como ha señalado F. Calero, había una razón circunstancial que podía motivar el escrito: una nueva mentalidad sobre el problema de la mendacidad estaba recorriendo Alemania, los Países Bajos, Inglaterra y España. El mismo Erasmo había escrito, dos años antes, el Diálogo de los mendigos (1524), donde se plasma dicha mentalidad ${ }^{10}$, que considera la pobreza perniciosa socialmente, pues la mendacidad es sinónimo de ociosidad, aunque también se critica al opulento por su falta de virtud. Y en esta obra ya se habla de que pronto no se permitirá que los mendigos vayan de una ciudad a otra, sino que cada ciudad podrá albergar sólo a sus propios mendigos. No cabe la hospitalidad para el extraño, es lo que viene a decirse. Además, la mendicidad es nido de delitos, por lo que se hace todavía más recomendable dicha política. Estas ideas, cada vez más extendidas, las conoce Vives, y habrá que ver cómo se posiciona ante las mismas. Y lo hará con valentía y originalidad. En efecto, en este contexto, Vives no sólo da pruebas de lo novedoso con su enfoque de la pobreza, sino que, incluso, es tal su alcance de miras, que cabe incluso reconocerle plena actualidad ${ }^{11}$.

Vives aspiraba a la supresión de la mendacidad mediante la integración. No es de extrañar, por tanto, que su obra causara verdadero impacto, y fuera atacada incluso años después, en 1562 por Gilles Wyts, y en 1564 por fray Lorenzo de Villavicencio, quien acusará a Vives de intromisión en materias que son de competencia eclesiástica, como la caridad. Villavicencio, confesionalista y censor, consideraba que el municipalismo defendido por Vives implicaba una herejía de tufo luterano, pues la beneficencia dejaba de estar en manos del poder eclesiástico, para estarlo bajo la jurisdicción del Consejo municipal. Pero la novedad de la propuesta vivista no quedará aquí, sino que también contemplará la atención dispensada a los niños, quienes carecían de todo valor y estima en su tiempo. Y del mismo modo, sus ideas sobre la integración de los discapacitados, o la dignificación del trabajo manual, considerado en la época de modo servil ${ }^{12}$, otorgan a su enfoque una extraordinaria actualidad.

Pues bien, ante el problema de la pobreza, Vives se decantará por una solución mixta, combinando la respuesta tradicional, centrada en la caridad (beneficencia privada), y aquella que responsabiliza a las instituciones políticas de dicho problema (beneficencia pública). Tal es la novedad de su propuesta, ante las insuficienciencias y contingencias de las actitudes individuales frente a la enormidad de la problemática ${ }^{13}$.

Un primer paso, sin duda fundamental, tanto para la respuesta privada como pública, y que Vives tiene muy presente, es cambiar nuestra mirada sobre el pobre.

10 Cfr. Calero, F., Ibidem, p. 18.

11 Cfr. Moreno Gallego, V., La recepción hispana de Juan Luis Vives, Biblioteca Valenciana, Colección Duque de Calabria, Generalitat Valenciana, 2006.

12 Cfr. Moreno Gallego, op. cit., pp. 446-450.

13 Así parece reconocerlo el propio Vives en la Dedicatoria y exposición de motivos de su De subventione pauperum. 
Pero en ningún momento opta nuestro autor por una semblanza idealizante de aquél; antes al contrario, trata de que sea una mirada veraz y responsable: es cierto que su aspecto, normalmente, es sucio y descuidado, y que incluso, a veces, en su conducta externa, los pobres son malos y hasta desagradecidos, nos dice ${ }^{14}$. Pero Vives trata de que nos corresponsabilicemos y nos preguntemos qué hemos hecho nosotros para evitar que lleguen a tal estado de menesterosidad y de corrupción ${ }^{15}$. Aquí la crítica vivista de la situación pretende que revisemos nuestros modos de vida, centrados en el amor desmesurado a nosotros mismos, la soberbia y la vanidad, dejando en muy mal lugar a la generosidad y el cuidado para con el necesitado ${ }^{16}$.

Transformar la mirada, preguntarnos qué responsabilidad tenemos, como individuos, ante el pobre y la situación a la que ha llegado, y qué podemos hacer como individuos, es, sin duda, un frente fundamental. Pero no es el único. El institucional será el otro gran ámbito en donde habrán de tomarse, prudente y diligentemente, las medidas necesarias para paliar tan escandalosa situación. Porque la caridad privada no basta, y es necesario que el gobernante se comporte como un buen pater familias, pues, nos dirá Vives, ¿qué padre dejaría a un hijo pasar hambre, o que viviera en condiciones tan lamentables de escasez? El fuerte, por voluntad de Dios, ha de ser guardián del débil ${ }^{17}$. Y aquí estriba la principal originalidad del enfoque vivista ${ }^{18}$.

Sin duda, entre las razones primeras que justifican el compromiso con los pobres están las que nacen de la esencia misma del cristianismo, de la caridad cristiana. No podemos alardear de ser buenos cristianos, y despreocuparnos de la pobreza de quienes son nuestros hermanos, mostrando así un corazón de hierro ${ }^{19}$, pues, como nosotros, son igualmente hijos de Dios, y por todos se ofreció Cristo $^{20}$. Pero a estas razones de coherencia con la fe se suman otras más pedestres, aunque no menos importanes, nacidas de la prudencia, relativas a la salubridad pública, al orden y a la paz social ${ }^{21}$, que vienen a reforzarlas. Del mismo modo, la originalidad del enfoque vivista se hace patente en su crítica a la desigualdad social entre los hombres, que tiene su raíz en la insaciable avaricia ${ }^{22}$. En efecto, si en una situación originaria había bienes para todos, poco a poco la soberbia y la ambición fueron creando desigualdades cada vez mayores entre los hombres, hasta llegar

14 Cfr. VIVes, Dsp Libro I, capítulo VIII.

15 Cfr. Idem.

16 La soberbia es para Vives el origen de todos los males humanos, de la ambición, y del consecuente olvido de los otros, mientras no favorezcan al interés propio. Cfr. Ibídem, Libro I, capítulo I.

17 Cfr. Ibidem, Libro I, capítulo X.

18 Cfr. Calero, F., Introducción a Dsp, pp. 22-25.

19 Cfr. Vives, Dsp, Libro I, capítulo VI.

20 Cfr. Ibídem, Libro I, capítulo XI. En este punto es interesante llamar la atención, como lo ha hecho Coronel Ramos, sobre la importancia del cristocentrismo vivista (que lo acerca a posiciones espirituales heterodoxas de la época), no sólo para la discusión teológica del momento, sino porque de su concepción religiosa emergerán, poco a poco, sus propuestas morales y políticas. Cfr. CORONEL Ramos, M. A., «Reflexiones sobre Juan Luis Vives y la tradición conversa del Cuatrocientos», en eHumanista 26 (2014), pp. 379-396, p. 385.

21 Cfr. Vives, Dsp, Libro II, capítulo I.

22 Cfr. Ibídem, Libro I, capítulo IX. 
a la situación actual, en la que reina una total desigualdad ${ }^{23}$. Y ello, piensa Vives, también es insostenible desde el punto de vista del orden y de la estabilidad social.

Por otra parte, especial importancia en el análisis de Vives, sobre la problemática que nos ocupa, juega el tema de la fortuna ${ }^{24}$. En este punto, los ecos de su formación clásica quedan bien patentes. En efecto, no son pocos los que padecen los estragos de la caprichosa fortuna, y aquí, nos dirá, no podemos disculpar nuestra responsabilidad para con el que la sufre. Vives quiere subrayar el componente fortuito que, en tantas ocasiones, tiene el ingresar en las filas de la pobreza. Y tal insistencia tiene un doble efecto: de un lado, exculpar al pobre de responsabilidad por la situación en la que cae envuelto, pues siempre hay aspectos que escapan a nuestro control y que, sin embargo, pueden modificar sustancialmente nuestras vidas. Y tales circunstancias son, la mayoría de las veces, imprevisibles, y por ello se dice que la noria de la fortuna lo mismo sube que baja, y no deberíamos perder de vista que a cualquiera podría sucederle lo mismo, y verse arrastrado a tan penosa situación ${ }^{25}$. Éste es, sin duda, un argumento poderoso con el que Vives pretende movilizar la voluntad del gobernante, porque exime al pobre que ha caído en desgracia de una responsabilidad que le desborda; a la vez que nos recuerda nuestra exposición a dichas contingencias, por lo que parece que estaría sugiriendo Vives que si todos querríamos, lógicamente, ser ayudados en caso de caer en semejante desgracia, ¿con qué derecho privamos al otro de tal atención y cuidado? ${ }^{26}$

Por tanto, Vives en ningún momento pretende dibujar una semblanza idealizada del pobre. Sabe que en muchas ocasiones no le son imputables la calamidad en la que viven él y los suyos. Y en su crudo enfoque sobre la pobreza llega incluso a considerarla como una enfermedad que, como tal, si no se atiende correctamente, correremos el riesgo de que se extienda como una plaga sobre toda la sociedad ${ }^{27}$. Lo que entendemos que Vives está sugiriendo es que la comunidad social es un todo orgánico, y que, al igual que sucede con el cuerpo, si permitimos que una parte esté en condiciones miserables, enfermará, y la enfermedad, de no afrontarse adecuadamente, se expandiráa ${ }^{28}$. No es, pues, el problema de la pobreza algo que afecte sólo a otros, podíamos pensar, sino que irá minando la salud y la vitalidad del todo en su conjunto. Pero, como decíamos, Vives no pretende dar una imagen idealizada del pobre, y cree, además, que aquellas conductas que puedan ser

23 Cfr. Ibídem, Libro I, capítulo VIII.

24 Cfr. Ibídem, Libro I, capítulo IV. Libro II, capítulo VII. Para un estudio comparado del problema de la fortuna, aunque no tanto en el tema que nos ocupa, sino en el contexto filosófico y cristiano del Renacimiento, cfr. Coronel Ramos, M. A., «Juan Luis Vives ante la fortuna», Estudios humanisticos. Filología, no 33, pp. 45-72, 2011.

25 Cfr. Vives, Dsp., Libro I, capítulo IV. Libro II, capítulo VII.

26 Cfr. Ibídem, Libro I, capítulo V.

27 Idem.

28 Ésta es una idea muy arraigada en Vives. De aquí que resulte muy cuestionable la concepción idividualista de Vives que algunos autores han dado, basándolo en un supuesto agustinismo que se enfrentaría al aristotelismo de la escolástica, y que no hace justicia ni a la fragilidad y contingencia del ser humano, ni a la dependencia que muestra de otros seres humanos, por no decir de su exposición a los caprichos de la fortuna. Cfr. Benítez Prudencio, J. J., «La repulsa de la diversidad: el pensamiento de Juan Luis Vives en el contexto de la lucha política-religiosa del siglo XVI», Daímon. Revista de filosofía, 2, pp. 335-336, 2008, pp. 329-336. 
delictivas, no se pueden consentir bajo ningún concepto ${ }^{29}$. Sin embargo, que esto ocurra en algunas circunstancias no nos exime de nuestra responsabilidad para con aquél, por las distintas razones que se vienen aduciendo. Y ha de hacerse tanto privada como públicamente ${ }^{30}$. Más aún, Dios mismo consiente la pobreza, porque, entre otras cosas, si fijamos nuestra atención en ella, esto nos llevará a comprender que su remedio exigirá de nosotros un cambio de actitud moral fundamental ${ }^{31}$, pues habremos de asumir nuestra parte de culpa, nuestra responsabilidad ante la situación en la que, en muchas ocasiones, caen aquellos. Porque, si bien las causas de su desgracia pueden escapar a nuestra voluntad, y son, en buena parte, imputables a la fortuna, sin embargo, la situación degradada a la que llegan, tanto en lo material como en lo moral, obedece, en gran medida, a nuestra desidia y despreocupación, ya que, con frecuencia, tardamos mucho en socorrerlos, o no lo hacemos con la extensión y alcance que hubieran requerido ${ }^{32}$.

Nuevamente, según lo entendemos nosotros, la originalidad del enfoque vivista va más allá de la solución mixta (beneficencia privada y pública) propuesta. A nuestro entender, lo novedoso del planteamiento radica en que, tanto el análisis, como la solución que Vives da al problema, pasan por el cambio en el modo de ver al otro, y por la autocrítica de actitudes y formas de vida que fomentan la pobreza. Aquí habría que situar su denuncia de que gran parte de las riquezas se amasan arrebatándole al pobre lo que es suyo, bien mediante grandes rapiñas, bien mediante fraudes ${ }^{33}$. Éstas, pues, serían causas ajenas a su voluntad, al depender directamente de quien les roba o les engaña. Con lo que vuelve a surgir el tema de la responsabilidad para con aquél, ya que no se debe culpar a ningún designio o ley divina, sino a las deficiencias del sistema socio-económico, establecido por los propios hombres ${ }^{34}$.

Sin embargo, no debemos pensar que, pese a las críticas de Vives a la acumulación sin escrúpulos de riqueza, éste estaría proponiendo abolir la propiedad privada. Tal inferencia no sería correcta. Vives cuestiona el afán desmedido de lucro, o los modos inapropiados de obtenerlo, mas no la propiedad. De hecho, en De communione rerum, lo que hará Vives es atacar a los anabaptistas, defensores a ultranza de la comunidad de bienes, y que, además, practican todo tipo de vicios, amparándose en tal comunidad. Pero, a su vez, que Vives defienda la necesidad de una propiedad privada no significa que los propietarios no tengan obligaciones para con la comunidad, y, de un modo muy particular, para con aquellos que más ayuda precisan. Sin embargo, sería un total anacronismo hablar de socialismo o de comunismo en Vives ${ }^{35}$, como han hecho otros, pues, como muy bien ha destacado F. Calero, hay que hablar más bien de función social de la propiedad ${ }^{36}$, tanto privada como pública, pues lo que hay es una responsabilidad moral y social para con aquellos que más lo necesitan. Los motivos que justifican tal exigencia, como

\footnotetext{
29 VIVEs, Dsp., Libro II, capítulo I.

30 Cfr. Ibídem, Libro I, capítulo III.

31 Cfr. Ibídem, Libro I, capítulo XI.

32 Cfr. Ibídem, Libro I, capítulo VIII; Libro II, capítulo IX.

33 Cfr. Ibídem, Libro I, capítulo XI.

34 Cfr. De la Iglesia, op.cit., pp. 9-12.

35 Cfr. Bataillon, M., op. cit., p. 185.

36 Cfr. Calero, F., Introducción, op. cit. pp. 31-46.
} 
venimos apuntando, van desde las razones religiosas - la charitas cristiana-, hasta las de carácter prudencial, para salvaguardar la paz social; pero también las de justicia, motivadas por su carácter humanitario. Y ahí aflora el Vives más impresionado y crítico con la situación que los pobres padecen.

Vives defiende, en la medida en que todos somos hijos de Dios, la igualdad de todos los hombres ${ }^{37}$, y, en consonancia con ello, concibe la ciudad como una hermandad, en la que el gobernante debería ejercer de pater familias, y los ciudadanos comportarse como hermanos que han de cooperar en pro del interés privado y común, y socorrerse mutuamente en la necesidad, pues todos necesitamos de todos ${ }^{38}$. Queda lejos la armonía en la que vivieron los primeros cristianos, pues pronto harán su aparición el egoísmo y la ambición, y el deseo creciente de propiedad privada. Sin embargo, no se trata, como decíamos, de abolir dicha propiedad, sino de que ésta cumpla con la función social que tiene encomendada en el seno de una comunidad en la que todos somos hermanos, en tanto hijos de Dios. Por ello, los santos Padres de la Iglesia ya nos advirtieron de semejante responsabilidad, aunque Vives sea el primero en hacerlo en la Edad Moderna ${ }^{39}$.

En efecto, Vives parte de la idea cristiana de que todos somos hijos de Dios $\mathrm{y}$, por tanto, iguales y hermanos ${ }^{40}$. La sociedad ha de entenderse, pues, como un sistema en el que ha de regir la corresponsabilidad. Por ello, el socorro de los pobres no puede dejarse a merced de los vaivenes del corazón compasivo. La responsabilidad ante el pobre es de todos, y por eso no puede quedar sólo en manos privadas, expuesta a limitaciones y contigencias. Es necesario dar una respuesta institucional permanente a dicha problemática. La gran aportación positiva de Vives radica aquí, precisamente al subrayar los naturales límites de la beneficencia privada, y la consiguiente necesidad de munipalizar la respuesta. El municipio es el que habrá de tomar las medidas precisas para que, descartada la posibilidad de fraude, el pobre sea debidamente atendido, a la vez que éste pueda hacer alguna aportación a la comunidad ${ }^{41}$ que, a su vez, lo ampara y protege ${ }^{42}$. Como decíamos, Vives concibe la sociedad como una familia, y esto significa, entre otras cosas, que no cabe desentenderse de sus miembros, pero que, al mismo tiempo, todos hemos de poder actuar en beneficio de todos. De alguna manera, la justicia, tal como Vives la entiende, tiene, diríamos, un camino de ida y vuelta, en el sentido de protección del necesitado, por un lado, y contraprestación a la comunidad que le protege, por otro. Porque Vives prevee todo un conjunto de medidas que habrá que ir mejorando, para que los pobres puedan contribuir al bien común, y no sean considerados por el resto de la comunidad como una carga social. Censar a los pobres, registrando sus datos y particulares necesidades, para luego recibir no sólo ayuda material, sino educación en modales, así como enseñárles un oficio, a la vez que participan de trabajos públicos, como colaborar en hospitales, o realizar tareas en beneficio de la comunidad, son las medidas que Vives, quien podría ser el mismo autor de

\footnotetext{
37 Cfr. VIVEs, Dsp, Libro I, capítulo VIII.

38 Cfr. Ibídem, Libro I, capítulo IV.

39 Algo en lo que ha insistido, Calero, F., op.cit., p. 46

40 Cfr. Vives, Dsp, Libro I, capítulo VIII.

41 Cfr. Ibidem, Libro II, capítulo III.

42 Cfr. Ibídem, Libro II, capítulo V.
} 
El lazarillo de Tormes ${ }^{43}$, cree necesarias para evitar el vagabundeaje, la ociosidad, y otros vicios asociados a ella, así como el que los pobres sean estigmatizados negativamente por la misma sociedad que los acoge ${ }^{44}$. De este modo, al contribuir al bien común ${ }^{45}$ con su aportación, en la medida de las posibilidades de cada uno, se restablece la dignidad del pobre, porque éste ya no es considerado como una carga, sino como uno más de la familia social. Y tal es la importancia de tomar medidas inclusivas que, hasta los ciegos, nos dirá adelantándose a los tiempos en los que afortunadamente hemos visto realizada su propuesta, pueden y deben realizar trabajos con arreglo a sus capacidades ${ }^{46}$.

Que Vives defiende la dignidad del hombre está fuera de duda, y lo justifica recordándonos que Dios lo creó de tal manera que no hubiera otro ser más excelente bajo el cielo ${ }^{47}$. Pero además de tratar de solventar una situación concreta, que se agrava día a día con la afluencia de pobres que llegan a las ciudades, Vives no descuida la ocasión que la realidad le brinda para hacer una reflexión crítica sobre el hombre y sus pasiones, así como sobre las condiciones de vida que favorecen o ponen en peligro dicha dignidad, analizando las causas de la miseria, y llegando a la conclusión de que detrás suya está el hombre, teniendo a la soberbia como la principal causante. En efecto, la misma soberbia que expulsó al hombre del paraíso, según el relato bíblico, es la que alentaría a la envidia, la ambición y la guerra, fuente de tantos vicios y desgracias, generadora extraordinaria de injusticias y de pobreza $^{48}$. La soberbia humana se manifiesta en el deseo de «ser como dioses», de erigirse en jueces del bien y del mal, en el mito adánico, pero también estaría detrás del deseo de sobresalir por encima de los demás, y, nos dice Vives, «de oprimirlos para que sin trabajar y honrados disfrutasen de los trabajos ajenos y los demás ejecutasen sus órdenes ${ }^{49}$. La historia humana se entreteje, pues, de ambición y dominación. Por ello, afirmará, de la soberbia nacen también la codicia de los gobernantes, las guerras civiles y externas.

Vives es consciente de que la pobreza en la que han venido a parar tiene distintas causas: por cesar en el trabajo, enfermedad, guerra, o por otras calamidades sobrevenidas $^{50}$. Llama la atención, por tanto, que Vives no se contente con dar una respuesta fácil, acostumbrada, y descalificadora del pobre, como hubiera sido decir que la pobreza es un estado en el que éste cae por sus propios vicios, entre los que estaría la pereza. Vives sabe que en algunos casos puede darse tal circunstancia, pero que hay otras muchas situaciones en las que intervienen causas ajenas a la propia voluntad. Y es de justicia reparar dicha situación en la que, dicho sea de paso, también podríamos vernos algún día todos. Porque, nos dirá Vives, Dios ha

43 Tesis que F. Calero viene defendiendo insistentemente en sus distintos trabajos, y en particular, y con mayor extensión en CALERo, F., Juan Luis Vives, autor del Lazarillo de Tormes, València, 2006.

44 Cfr. Vives, Dsp, Libro II, capítulos II-III.

45 Cfr. Ibídem, Libro II, capítulo IX.

46 Cfr. Ibidem, Libro II, capítulo III.

47 Cfr. Ibídem, Libro I, capítulo I.

48 Cfr. Ibídem, Libro I, capítulo I, V.

49 Ibídem, Libro I, capítulo II.

50 Cfr. Ibídem, Libro II, capítulo III. 
querido contrarrestar la soberbia humana haciéndonos a todos indigentes ${ }^{51}$, pues todos necesitamos, constantemente, y de un modo u otro, la ayuda de los demás. ${ }^{52}$

Pero al hacernos Dios indigentes, necesitados unos de otros, nos dirá, todos somos, en algún sentido, pobres, aunque normalmente reservemos tal nombre para quienes caen en una situación de miseria extrema, por lo que demandarán no limosna, sino misericordia, es decir, actuaciones concretas orientadas a aliviar y paliar tan dramática miseria ${ }^{53}$.

Y si importante es la idea de que, a lo largo de la vida, todos acabaremos necesitando unos de otros, y todos podríamos incluso llegar a ser pobres, no menos importante será la idea de Vives de que el pobre no sólo necesita dinero, ayuda material, para reparar su situación, sino también de otros bienes, igualmente necesarios, para poder llevar adelante una vida propiamente humana. El pobre no sólo requiere atención en lo relativo a su cuerpo (alimento, higiene, salud), sino también en lo relativo a su alma, pues la virtud es el único y verdadero bien, por lo que es preciso educarle en tal sentido, y a partir de aquí, cultivar su inteligencia, agudeza, instrucción, deliberación y prudencia. Esta atención integral ${ }^{54}$ le servirá para cuidar mejor de su propio cuerpo, dinero, posesiones y hacienda en un futuro ${ }^{55}$. De aquí que sea importantísismo poner remedio al abandono en el que malviven muchos niños, cuidando de su inteligencia, erudición y buen juicio para la vida ${ }^{56}$.

Pero insistamos en que la idea de indigencia humana le lleva a rebajar las pretensiones de la soberbia, fuente de toda injusticia ${ }^{57}$. En este sentido, Vives trata de reforzar la búsqueda del bien común, máxime cuando todos necesitamos de todos, y de distinto modo, según tiempos y circunstancias de la vida de cada cual. Porque todos somos humanos, y estamos igualmente sujetos a la rueda de la fortuna ${ }^{58}$. Pero a la vez, por razones que dicta la prudencia, nos recuerda que procurar el bien común es lo más inteligente para salvaguardar la estabilidad de un régimen. De aquí que concluya: «Un estado es justo y un poder es saludable si las preocupaciones y las determinaciones de los gobernantes van referidas al

51 Vives insiste en que esta indigencia va más allá de la mera necesidad de dinero. La soberbia humana tiene como contrapartida el que Dios nos ha hecho dependientes unos de otros, y por tanto, necesitados: «Así todo el hombre, interna y externamente, se convirtió en indigente por la justísima recompensa del trabajo emprendida para usurpar la divinidad; fue aplastada la soberbia de este ser engreidísimo de forma que no hay nada más débil que él ni que valga menos por sí mismo: toda su vida y su salud descansan en las ayudas de los demás, tanto para reprimir la raíz de la soberbia, que se transmite a los descendientes por los fundadores del linaje, como también especialmente por los designios ocultos de Dios, de forma que a unos falta dinero, a otros salud o inteligencia, que utilizarían mal; para otros esta pobreza es instrumento de grandes virtudes, pues todo lo dirige a nuestra utilidad el gran príncipe y gobernador de este mundo, Padre sapientísimo y misericordiosísimo. Así, pues, quien necesita la ayuda ajena es pobre y necesita la misericordia, que en griego se dice eleemossýne, situada no solo en la distribución de la limosna, como piensa el vulgo, sino en toda obra que alivia la indigencia humana». Cfr. Ibídem, Libro I, capítulo II.

52 Cfr. Ibídem, Libro I, capítulo IV.

53 Cfr. Idem.

54 Vives insistirá siempre en la necesidad de no descuidar ni el cuerpo ni el alma, pues la persona abarca una totalidad, como el mismo cristianismo sostiene. Cfr. Ibídem, Libro I, capítulo X.

55 Cfr. Ibídem, Libro I, capítulo III.

56 Cfr. Idem.

57 Cfr. Ibídem, Libro I, capítulo IV.

58 Cfr. Idem. 
bien público ${ }^{59}$. Además, debemos hacerlo por razones humanitarias, porque la generosidad es un deseo que nace del corazón humano, y además sería inhumano y hasta contra natura, no ayudar al que lo necesita. Pero por si fueran poco estas razones, Vives nos recuerda que también nos manda Cristo ocuparnos del pobre ${ }^{60}$, a la vez que las sociedades humanas no podrán subsistir si en ellas no se practicaran el bien y la justicia ${ }^{61}$.

Como hemos apuntado, Vives describe con gran realismo la situación en la que se encuentra aquél. Y entre los escollos que es preciso remover para hacerse cargo de su difícil situación, nos dirá, el principal de todos nace de nosotros mismos, pues con frecuencia cuestionamos la utilidad misma de dicha atención. Muchos, nos dirá, no creen en la beneficencia privada, por su alcance limitado e inconstante, por lo que estiman que no servirá de nada al pobre ${ }^{62}$. Tal pesimismo lo combatirá Vives, subrayando que aunque no puedan resolverse todos los problemas, tal beneficencia será siempre oportuna, dado el volumen de casos a socorrer. Por tanto, aunque Vives plantee la necesidad de abordar institucionalmente el problema, la solución privada, hasta donde pueda darse, será siempre necesaria y bien recibida.

Pero además del pesimismo, Vives tratará de remover otro escollo, más grave si cabe: la idea de que la beneficencia hacia los otros puede perjudicarnos ${ }^{63}$. Por ello, en primer lugar, intentará convencernos de que quien hace un bien ya recibe en sí mismo el beneficio de dicha práctica ${ }^{64}$. Pero es cierto que muchas veces nos encontraremos con la ingratitud de aquél a quien hacemos un bien ${ }^{65}$. Y en este punto, Vives traza un retrato muy áspero, sin maquillajes ni idealizaciones, de las más ingratas y viciosas actitudes de muchos pobres: sus prácticas inmoderadas en el pedir, su conducta procaz, su carácter inoportuno, que interrumpe actos de importancia, que hace incluso uso de la fuerza, o hasta se vale de los hijos para la mendacidad ${ }^{66}$. Pero también puntualiza que, si bien se dan en algunos tales censurables conductas, juzgaríamos erróneamente a todos por igual ${ }^{67}$. No cabe duda de que la crudeza de las descripiciones que hace Vives no nace del deseo de aumentar aún más sus defectos, sino de dar más verosimilitud a sus argumentos y propuestas, pues parten de un conocimiento fiel de la realidad, sin falsos adornos. Por ello, nos parecen muy desafortunadas y profundamente erradas las palabras que al respecto M. Bataillon vierte sobre el gran humanista valenciano ${ }^{68}$. A nuestro

\footnotetext{
59 Idem.

60 Cfr. Ibídem, Libro II, capítulo X.

61 Cfr. Idem.

62 Cfr. Ibídem, Libro I, capítulo V, y también Libro II, capítulo VIII, dedicado a aquellos que desaprueban todas estas ideas y medidas.

63 Cfr. Ibídem, Libro II, capítulo X; y Libro I, capítulo V.

64 Cfr. Ibídem, Libro I, capítulo X.

65 Cfr. Ibídem, Libro I, capítulo V.

66 Cfr. Ibídem, especialmente Libro I, capítulo V, donde Vives hace el retrato más crudo de
} la realidad que padece el pobre, y de sus prácticas, sencillamente con la intención de evitar falsas idealizaciones y dar plena verosimilitud a su escrito.

67 Cfr. Ibídem, Libro I, capítulo V.

68 Ante el retrato social de la pobreza; y del pobre, sostiene Bataillon sobre Vives y su concepto de la mendacidad, que aunaría tanto el humanismo cristiano como el ideal mercantilista de una burguesía naciente que necesita de mano de obra para desarrollar su empresa Cfr. BATAILLON, op.cit, pp. 181-2. Más aún, nos dice de Vives contra los pobres: «Desde luego es el puritanismo burgués 
juicio, con el detallismo del relato Vives evita enmascarar la situación real, que de hecho, sufren muchos pobres. Y sin embargo, y precisamente por ello, defenderá la necesidad de la beneficencia pública y privada. Ingratitud, codicia, soberbia,

el que expresa por sus labios su indignación ante la inmoralidad de una chusma cien veces más ávida de goces que los posedentes, cínicamente derrochadora de un dinero que no ha ganado con su trabajo. Ibídem, pp. 186-7. Sorprende, pues, esta visión de Vives a caballo entre el humanismo cristiano y el burgués interesado en tener mano de obra barata disponible. A quien haya leído De subventione pauperum creemos que no dejará de sorprenderle el distorsionado retarato que Bataillon hace de Vives, más preocupado por los egoístas ideales de la burguesía naciente que por hacer justicia, humana y cristianamente, a los más desfavorecidos. Para Bataillon,Vives es un hombre delicado, que huye de la roña de Alcalá, la tristeza de Oxford y de Londres, y se instala en Brujas, la «ciudad amiga del hombre». Ibídem, p. 187, y es ahí donde Vives se propondría una operación de «limpieza» que va a purificar a la ciudad. Habrá que censar a todos los mendigos, y ponerlos a trabajar. En Vives habría una utopía del trabajo, pero bien distinta de la de Moro, que quería reducir la jornada de trabajo. Vives, más pesimista, sigue la línea de la maldición del Génesis. Cfr. Ibídem, p. 189. Para Vives el problema de la abolición de la mendacidad tiene que ver con la necesidad de que se encuentre mano de obra para el artesanado y el sector textil. Cfr. idem.

En definitiva, la interpretación - sorprendente y completamente distorsionada con respecto a los textos, en nuestra opinión- que hace Bataillon de Vives es ver al humanista valenciano, incluso, como a un enemigo de la mendacidad, pero en unos términos en los que parece que el humanista arremete, incluso, contra los que la padecen, los pobres mendigos, considerados como mera escoria. Su destino es o la cloaca o la fábrica, donde prácticamente viven como en un campo de trabajo: «Todo el sistema expuesto por Vives tiende, sin que él lo diga en ninguna parte de un modo rotundo y agresivo, a la supresión radical de la mendicidad. Implica, junto con la severa ley del trabajo para todos, una reforma no menos severa de los hospitales, es decir, de los asilos. Dentro del gran debate secular, especialmente vivo en el siglo XVI, que opone a los adversarios y a defensores de la mendicidad, Vives se sitúa resueltamente entre los primeros, los que querían encerrar a los tullidos e incurables sin recursos entre las paredes de un hospital, o al menos prohibirles la libertad mendicante en la que Irides encontraba tantos atractivos.(...) Aunque los asilos que él concebía no eran cárceles, sí eran lugares de los que sólo se salía para ir al taller. No vemos que se esforzase demasiado para multiplicarlos. Como máximo prevé la fundación de algunos hospitales nuevos para los enfermos pobres, sobre todo para los contagiosos. Una ciudad al obrar así imita a la naturaleza o a los constructores de naves, que disponen una cloaca o sentina para aislar los residuos. El enfermo que sane saldrá de la sentina social para volver a su lugar de trabajo, a menos que no prefiera quedarse con sus hermanos de infortunio para servirles.»Ibídem, pp. 191s. Y más adelante vuelve a sugerir la imagen de un Vives preocupado por allanar el camino a la burguesía capitalista incipiente: "No subestimemos el radicalismo reformista de Vives, o si, se prefiere, de la burguesía cosmopolita de la que es el intérprete. Comprendamos más bien que suavizó deliberadamente sus aristas». Ibídem, p. 199.

En la concepción de Bataillon, pues, la crítica de Vives al tema de la pobreza obedecería a razones interesadamente mercantiles, orientadas a «limpiar» las ciudades, y encontrar mano de obra para la industria incipiente. De ningún modo estarían presentes en él ni razones humanitarias, ni cristianas. Pero a nuestro entender, y es lo que estamos tratando de mostrar en este trabajo, es patente que el enfoque de M. Bataillon sobre los pobres en Vives desfigura totalme las ideas principales que el humanista español defiende expresamente en su obra, por lo que la lectura de Bataillon no pasa de ser una grotesca deformación o caricatura de mal gusto, que no se compadece ni sostiene mínimamente con los textos vivistas, ni en el espíritu, ni en la letra, y que es, cuanto menos, incomprensible, por lo que, a buen seguro, suscitará en el lector de Vives la perplejidad, por proceder tales afirmaciones de quien se supone que es toda una autoridad en el estudio del humanismo. Sólo cabe esperar que otros autores hayan corrido mejor fortuna, en aras a la verdad. A nuestro juicio, es bien patente en Vives el deseo de denunciar un mundo lleno de ambición, de lujo, de vanidad, de transacciones comerciales y ganancias sin límite mientras muchos se pudren en la pobreza más injusta. 
arrogancia, voracidad inhumana, desvergüenza, lascivia son todo un catálogo de vicios que dibujan, en gran medida, la realidad degradada en la que viven muchos de los que, con frecuencia, transitan las calles de Brujas, y las de tantas otras ciudades. Vives quiere ofrecer credibilidad a todo cuanto argumenta, y viabilidad a todo cuanto propone, y por ello necesita hacer una descripción fidedigna, por desagradable que sea, de lo que de hecho y normalmente acontece bajo el manto de la pobreza. Pero no quiere que tal inventario se tome por algo que, necesariamente, tenga que darse así en todos los lugares. Vives insiste en que los pobres no tienen por qué comportarse del mismo modo en todas partes. Sólo que, en su relato de los hechos, evita que podamos tacharlo de idealista, o de ingenuo. No obstante, y a pesar de lo exhaustivo del repertorio de vicios que, al parecer, es frecuente encontrar entre la gente pobre, Vives recalcará que en su descripción ha hablado en términos muy generales, y que no sería justo aplicarla a todos. Sin embargo lo que sí cabe atribuir a todos los pobres es que comparten el hecho de la pobreza, y eso sí que nos exige a todos, dirá nuestro autor, que se amplíen nuestras ayudas, y que se actúe siempre con la máxima celeridad, para detener su avance, y el de los vicios y delitos que tantas veces la acompañan. Y de un modo muy especial, dirá Vives, hay que socorrer, y cuanto antes, a los más débiles de todos, a saber, a los niños ${ }^{69}$, quedando también en este punto patente la novedad de la propuesta vivista, habida cuenta del escasísimo, por no decir nulo valor, que se le otorga al niño en la época ${ }^{70}$.

Vives ha trazado, pues, un retrato muy preciso de los vicios que tantas veces acompañan a los pobres, aunque ha matizado que tales vicios no tienen por qué ser generalizados. Y menos aún quiere que caigamos en el error de estigmatizar y de justificar tales vicios, bajo el insalvable pretexto de la pobreza. Ni todos los pobres son así, ni va en la situación de pobreza serlo, por más que muchos se comporten de tal modo. Por ello, cree imprescindible la educación en la virtud, y que, consecuentemente, los pobres aprendan a mostrarse moderados, que pidan con rectitud ${ }^{71}$, y eviten igualmente los vicios comunes a todo hombre, como la soberbia, la ingratitud, la envidia, la arrogancia, sin olvidar la raíz y principal causa de todos los vicios: la ociosidad ${ }^{72}$. Insistirá Vives, por tanto, en la necesidad de que los pobres se eduquen en la virtud, y también sus hijos, pues todos los vicios han de ser combatidos con la formación, conscientemente orientada a dicho fin ${ }^{73}$.

Pero la educación moral la precisamos todos, por lo que no es algo que Vives crea exigible sólo para los pobres. Nuestros vicios, nuestros defectos morales, nos impiden ejercer con generosidad la beneficencia. Y el principal escollo estará en nuestro desmesurado amor hacia nosotros mismos, en nuestra soberbia, en el deseo de sobresalir sobre los demás, por cuyo motivo, dirá, acabamos oprimiéndolos ${ }^{74}$.

69 Cfr. VIVES, Dsp. Libro I, capítulo; Libro II, capítulo II.

70 Queremos destacar la novedad de la propuesta de Vives, según Moreno Gallego, dado el poco valor que en la época se le atribuía al niño. Cfr. Moreno Gallego, op. cit. pp. 449-50.

71 Cfr. Vives, Dsp, Libro I, capítulo VI.

72 Cfr. Ibídem, Libro II, capítulo X.

73 Cfr. Ibídem, Libro II, capítulo I.

${ }^{74}$ Cfr. Ibídem, Libro I, capítulo VII. 
Por otra parte, el lenguaje moral también se ha alterado, lo que explica, por ejemplo, que ahora el ahorro y la moderación sean mal vistos en comparación con el lujo y el despilfarro; y lo mismo sucede con la sencillez y la prudencia, que son tachadas de tonterías, si se comparan con la astucia y el engaño ${ }^{75}$. A todo ello se añade que el dinero ya no es un medio de sustento, sino un modo de aparentar prestigio, honor y dignidad, pues incluso se hace alarde de ello en los fastos mortuorios ${ }^{76}$.

Pero lo que tiene de nocivo el desmedido amor al dinero es que acaba no sólo modulando nuestro lenguaje moral y nuestra escala de valores, sino que apaga nuestro amor por los demás, al ensanchar el amor hacia uno mismo, a la vez que nos hace más proclives a distanciarnos de los otros, acusándoles de los males que padecen, culpándoles de todos sus vicios para, de ese modo, disculpar nuestra falta de generosidad para con ellos, mientras agrandamos, día a día, el pozo sin fondo de nuestra avaricia $^{77}$.

Vives va alternando, en su discurso, la remoción de obstáculos para la beneficencia, con argumentos que la incentiven. Así, no practicar la beneficencia nos hace inhumanos, a la vez que es una insensatez, pues compromete la estabilidad social. Del mismo modo, nos recuerda, no podemos reprochar a los pobres el que a veces sean desagradecidos, cuando nosotros mismos lo somos con Dios, mientras que, por el contrario, cuando practicamos la beneficencia nos hacemos imitadores de Cristo $^{78}$.

En cualquier caso, de entre los muchos argumentos que irá dando en pro de la beneficencia, pública y privada, y contra los pretextos que pretenden eludirla, creemos que el que cobra más fuerza es el que dedica a llamar la atención, precisamente, sobre nuestra responsabilidad por la situación calamitosa a la que ha llegado el pobre, y que dice muy poco de nuestra condición de cristianos. En efecto, ¿qué hemos hecho para remediar tal situación? ¿Y con qué celeridad y determinación nos hemos aplicado a su socorro? Más que culpar a los pobres de la situación degradante en la que se encuentran, deberíamos preguntarnos si hemos hecho algo para remediarlo:

«Además, si socorriéramos a tiempo a los pobres, sin ninguna duda cambiarían sus costumbres junto con su condición y su situación económica. Pero ahora dejamos que los mendigos se pudran en su pobreza. ¿Qué otra cosa pueden sacar de su miseria que todos esos vicios mencionados? Y ciertamente sus culpas son humanas y hasta cierto punto inevitables, pero las nuestras son voluntarias y diabólicas. ¿Qué significa, en efecto, que en las ciudades cristianas, en las que todos los días se lee el Evangelio, esto es, el libro de la vida y en él el único precepto, el amor, se viva de forma tan distinta a como allí se prescribe?» ${ }^{79}$.

Como decíamos más arriba, Vives no sólo se ocupa de la resolución práctica de un problema, sino que, además, se vale de dicha problemática para reflexionar sobre nuestras actitudes morales al respecto. En efecto, como buen cristiano, Vives nos recuerda que malgastamos nuestra vida si vamos en pos de las riquezas, ajenos

\footnotetext{
75 Cfr. Ibídem, Libro I, capítulo VIII.

76 Cfr. Ibidem, Libro II, capítulo VI.

77 Cfr. Ibídem, Libro I, capítulo VII.

78 Cfr. Ibídem, Libro II, capítulo VIII.

79 Ibídem, Libro I, capítulo VIII.
} 
al daño que hace también en nostros la avaricia: «Por la costumbre de los vicios nos hemos hecho insensibles, de tal forma que ya no apreciamos las cosas que tanto nos dañan ${ }^{80}$. Del mismo modo, tratará de que veamos el lado amable, agradabilísimo, nos dirá, de practicar la beneficencia, y por ello, tal virtud la ensalzaron, incluso, los autores paganos, como Platón, Jenofonte, Cicerón y Séneca ${ }^{81}$.

Citando a Platón, Vives subraya que los Estados serían felices si de la vida de los hombres fueran eliminadas las palabras mío y tuyo ${ }^{82}$. Pero no hay que ver en este comentario ningún ataque de Vives a la propiedad privada. Como ya hemos apuntado, Vives está en contra de la propiedad exclusivamente en común, tal y como predicaban los anabaptistas, a los que estaría atacando, y muy duramente, en su obra De communione rerum ${ }^{83}$. Por todo ello, el problema no estaría tanto en la propiedad privada como tal, cuanto en el déficit moral de los hombres que son arrastrados por la ambición, por la avaricia, que es verdadera fuente del mal, bloqueando toda generosidad y beneficiencia para con los más necesitados. Reconoce Vives que el hombre es así desde siempre, desde la caída, por el pecado ${ }^{84}$. Pero si tal es la condición humana, el problema estará, al menos, en tratar no de fomentar dicha actitud, sino en ver el modo de minimizar sus efectos, tomando conciencia de dónde está la raíz del mal que infligimos a otros:

«Así, pues, lo que la naturaleza en su generosidad nos dio en común, nosotros nos lo apropiamos por nuestra avaricia; lo que ella puso al alcance de todos nosotros lo apartamos, lo escondemos, lo encerramos, lo protegemos, apartando a los demás con puertas, paredes, cerrojos, hierro, armas y finalmente leyes. Por tanto nuestra avaricia y nuestra maldad introducen carestía y hambre en la abundancia de la naturaleza, y proporcionan pobreza a las riquezas de Dios» ${ }^{85}$.

Y lo primero que hay que hacer, sin duda, es asumir que todo lo que tenemos no nos pertenece realmente, sino que se nos ha concedido y dado, de algún modo por Dios, y que en realidad somos administradores de esos bienes o dones que poseemos, que ni debemos guardar para nosotros, ni despilfarrar, sino ponerlos siempre al servicio de los otros ${ }^{86}$. En este sentido, particularmente interesante nos parece que Vives haya subrayado que el hambre es fruto no de la carestía natural, porque Dios ha sido generoso con todos, sino que es obra humana, y obedece, pues, a nuestra maldad y nuestra avaricia. No hay, pues, excusas que valgan para seguir culpabilizando a los pobres de su situación, cuando somos nosotros mismos quienes con nuestro egoísmo, o bien provocamos su pobreza, o bien no hacemos nada por remediarla. En efecto, todo cuanto tenemos lo recibimos de Dios, y todo hombre debería considerarse meramente administrador de tales bienes, y no el destinatario final de los mismos ${ }^{87}$. Y por ello, Vives quiere modificar nuestro uso del lenguaje moral, y que tomemos conciencia de cuánta responsabilidad tenemos

\footnotetext{
80 Idem.

81 Cfr. Ibídem, Libro I, capítulo VIII.

82 Cfr. Ibídem, Libro I, capítulo IX.

83 Cfr. Calero, F., Introducción, op. cit., p. 36.

84 Cfr. Vives, Dsp, Libro I, capítulo II.

85 Ibídem, Libro I, capítulo IX.

${ }_{86}$ Cfr. Ibídem, Libro I, capítulo VIII.

87 Cfr. Idem, y también, Libro I, capítulo IX.
} 
al respecto, hasta el punto de afirmar, sin tapujos, que también nosotros somos literalmente ladrones, si nuestros bienes - materiales o culturales- no los ponemos, egoístamente, más que a disposición de nosotros mismos:

«Así, pues, que nadie ignore este hecho, que él no ha recibido su cuerpo, su alma, su vida y su dinero para su uso y utilidad exclusivos, sino que es administrador de todos esos bienes y que no los ha recibido de Dios con otro fin(...). Por eso es ladrón no el que quita al heredero lo que da a los pobres, sino el que emplea su erudición o gasta sus fuerzas inútilmente o deja que se emboten sus conocimientos, o derrocha o guarda el dinero.(...) He mostrado que nada es de nadie: es ladrón, repito, y raptor cualquiera que derrocha el dinero en los juegos de azar, quien lo mantiene en casa encerrado en arcas, quien despilfarra en fiestas o banquetes, quien despilfarra en vestimentas de mucho precio o en aparadores provistos de variadas piezas de plata y de oro, aquel a quien se le pudren en casa las vestimentas, aquellos que gastan el dinero en andar comprando cosas superfluas o inútiles, y los que lo hacen en construcciones inútiles; finalmente es ladrón quien no reparte a los pobres lo que le sobra de las necesidades naturales, y, si no es castigado por las leyes humanas, aunque también lo hacen algunas, con seguridad será castigado por las divinas.(...) El rico derrochador del Evangelio no es culpado porque hubiese adquirido su hacienda con robos y malas artes, sino porque la derrochaba de forma inmoderada y porque no socorría al mendigo Lázaro. No son tuyas estas posesiones, sino que se te han confiado; incluso si fuesen tuyas, ni las leyes divinas ni las humanas permiten que las despilfarres ni que hagas mal uso de ellas» ${ }^{88}$.

Es inhumano despreocuparnos de la suerte de los otros; y también es una imprudencia, desde la perspectiva de la paz social. Pero, igualmente, es una insensatez para con nosotros mismos, pues la rueda de la fortuna gira sin parar, y todos podemos vernos aplastados por ella ${ }^{89}$. Mas también dice muy poco de nosotros como cristianos. En efecto, el tema de la justicia está muy presente en profetas como David o Isaías, y vertebra todo el Nuevo Testamento. La avaricia atrapa al que cae en sus redes de tal modo que endurece su alma hasta el punto de que, citando a Pablo, aquellos que se dejan arrastrar por el deseo de riquezas se deslizan hacia la idolatría, y las convierten en su nuevo Dios ${ }^{90}$. Como nos dice el Evangelio, no se puede servir a dos señores, a Dios y al dinero (Mt 6,24; Lc 16,11). Por ello, no practicar la beneficiencia con el necesitado es una contradicción con la condición de cristiano propiamente hablando: «Pero ciertamente no veo con qué cara nos atrevemos los cristianos a confesarnos tales, cuando no hacemos ninguna de las cosas que Cristo mandó en primer lugar y casi con exclusividad» ${ }^{91}$.

Éste es uno de los argumentos centrales de Vives, pues se trata de dejar al descubierto que no hay otra opción para el cristiano que seguir el mandato y el ejemplo de Cristo para con los más pobres, y hacerlo íntegramente, cuidando de su persona, como totalidad de cuerpo y alma:

«El resumen es este: yo considero que nadie es cristiano si, en la medida en que puede, no socorre a su hermano necesitado. (...) Se preocupan de todo el

${ }_{88}$ Ibídem, Libro I, capítulo X.

89 Cfr. Ibídem, Libro I, capítulo II.

90 Cfr. idem.

91 Idem. 
hombre, lo alimentan y confortan en su totalidad, se afanan por ser útiles a todo él: al espíritu por medio de la predicación y de la santa doctrina, a los cuerpos en primer lugar con los milagros y con el poder de expulsar las enfermedades, que acompañaba a la predicación y a aquella firmísima fe, y con las ayudas para la vida reuniendo dinero con el que fuesen alimentados los indigentes. Esto es en verdad propio del cristiano y del seguidor de su príncipe y maestro, que hizo al hombre al completo, y lo curó y alimentó a todo él: el espíritu con su doctrina y el cuerpo con el alimento; así conviene que nosotros hagamos el bien al espíritu y al cuerpo, en la medida en que pueda cada uno ${ }^{92}$.

Vives aprovecha, igualmente, para hacer autocrítica, en particular sobre el lujo y el despilfarro, en el que tantas veces caemos, como si se tratara de necesidades ${ }^{93}$. Y siempre que puede nos recuerda que somos corresponsables de esa pobreza, por acción y por omisión, porque, nos dice, parte de nuestras riquezas se levantan sobre la pobreza de muchos, lo que significa que, con frecuencia, el rico lo es a costa del pobre. Y de aquí que sea todavía más necesaria la beneficencia ejercida con generosidad, ya que es el único modo de restablecer la justicia:

«Pero, para que nadie presuma de que de abundantes riquezas da también mucho a los pobres, hemos de ser advertidos de que no es agradable a Dios la limosna que es arrebatada por el rico del sudor y la ganancia de los pobres. ¿Cómo se califica, en efecto, que hayas expoliado a muchos por fraude, por engaño, por robo o por fuerza para repartir algo a unos pocos? ¿Cómo haber quitado mil para dar cien? En esto piensan algunos que cumplen su deber si de las grandes rapiñas o fraudes se redimen con alguna porcioncilla que den a los pobres, o con la que edifiquen una capilla pegando allí sus escudos, o bien adornen un templo con vidrieras o, lo que es más digno de risa, paguen al confesor para que los absuelva de sus culpas» ${ }^{94}$.

Por ello, si tales argumentos no fueran suficientes, Vives, además de apelar a la humanidad y a la prudencia, quiere animarnos a su práctica, recordando que obrando justamente nos hacemos un enorme bien a nosotros mismos, a la vez que nos ponemos en disposición de recibir la divina generosidad, de la que ya participamos anticipadamente en la alegría que sentimos al dar:

«Toda limosna tiene como una recompensa inmediata: ablanda el corazón endurecido, prepara para el arrepentimiento de nuestras faltas, y nos inunda de cierta dulzura. Todos experimentan esto en sí mismos: quien hace un beneficio a otro, con afecto por Dios, experimenta por su limosna un anticipo de la felicidad eterna ${ }^{95}$.

Y en cuanto al modo de practicar tal beneficencia, nos dirá, habrá de hacerse con alegría de ánimo y prontitud, anticipándonos a la humillación del que tiene que pedir, o evitando que la necesidad le empuje al delito o a la maldad. Y tal práctica, nos recuerda, ha de hacerse sólo a los ojos de Dios, dejando así de lado toda humana vanidad ${ }^{96}$.

\footnotetext{
92 Idem.

93 Cfr. idem.

94 Idem.

95 Idem.

96 Cfr. Idem.
} 
Pero como decíamos, Vives no descuida ningún frente, ni el individual, donde rige la moral cristiana, ni el institucional, público, donde apela a la responsabilidad del gobernante para con la paz social:

«Hasta aquí he dicho qué conviene hacer a cada uno en particular; en adelante qué conviene a la ciudad públicamente y a quien la gobierna, que es en ella lo que el alma en el cuerpo. Ella no anima o vivifica una u otra parte del cuerpo, sino el cuerpo entero, así el magistrado no ha de descuidar nada en su colectividad, pues los que se preocupan sólo de los ricos, despreciando a los pobres, actúan como si un médico pensase que no se ha de ayudar mucho a las manos o a los pies por estar lejos del corazón. Así como no se haría esto sin un grave daño para el hombre en su totalidad, de la misma manera en lo público los más humildes no son tan desatendidos sin peligro para los poderosos, pues aquéllos, oprimidos por la necesidad, en parte se dedican a robar; el juez considera indigno de él juzgar estas cosas; pero eso es de poca importancia: miran con malos ojos a los ricos, protestan y se indignan de que les sobre para alimentar bufones, perros, prostitutas, mulas, caballos y elefantes, mientras ellos no tienen qué dar a sus pequeños hijos hambrientos, así como de que los ricos utilicen con soberbia e insolencia las riquezas que les han quitado a ellos y a sus semejantes. No se creería con facilidad cuántas guerras civiles han suscitado en todos los pueblos estas protestas: en ellas la multitud, encendida e inflamada por el odio, lanza los primeros ensayos de su locura contra $\operatorname{los}$ ricos ${ }^{97}$.

Y no sólo la paz social. También la proliferación de enfermedades preocupa a Vives ${ }^{98}$, que trata de concienciar con ello al poder político, para que ponga remedio a la miseria. Como decíamos más arriba, las descripciones que hace Vives son crudísimas, y parece claro que con ellas quiere más impresionar e intimidar a los gobernantes, que presentar un retrato degradante del pobre, como cuando nos dice que, en su desesperación, los pobres se aproximan mucho, hasta desvergonzadamente, para pedir, o llegan a robar, o prostituyen a sus mujeres, y en cualquier caso, sus hijos padecen un abandono tal que hasta son apartados de los actos religiosos, pues nadie los quiere cerca ${ }^{99}$. Pero, y he aquí una de las tesis más directas e incisivas de Vives, todos somos culpables de semejante abandono, y de las consecuencias que se deriven para la comunidad. Por ello, cuando el gobernante se olvida de, o deja de lado su educación, acaba simplemente reprimiendo y castigando a aquellos a los que tampoco ha ayudado previamente ${ }^{100}$. A fin de cuentas, la ignorancia y escasez material que padecen los más pobres acabará poniendo en marcha toda una cadena de desgracias, por lo que la exclusión y el castigo serán el ámbito natural en el que los más necesitados, abandonados a su suerte, acabarán malogrando sus vidas, dejados de la mano de los que gobiernan, pero también de aquellos que, como cristianos, deberían haberse ocupado de ellos:

«Paso por alto el hecho de que algunos se mezclan a la multitud habiéndose apartado un momento antes del lado de uno muerto por la peste. Estas cosas no han de ser descuidadas por los que administran las ciudades, tanto para aliviar

97 Ibídem, Libro II, capítulo I.

98 Cfr. Abellán, J., Historia crítica del pensamiento español. La edad de Oro (siglo XVI), vol. 2, Barcelona, Círculo de Lectores, 1992, p. 145.

99 Cfr. Vives, Dsp, Libro I, capítulo V.

100 Cfr. Ibídem, Libro I, capítulo VIII. 
las enfermedades como para que no se extiendan a un número mayor. Además no es propio del magistrado sensato y celoso del bien público dejar abandonada una parte tan grande de la ciudad, no sólo inútil sino también perniciosa para sí misma y para los demás, pues, una vez cerrada la generosidad de muchos, al no tener de qué alimentarse, unos se ven obligados a robar a mano armada en la ciudad y en los caminos, otros roban a ocultas, las mujeres que tienen buena edad, dejada la vergüenza, no pueden mantener la honestidad, vendiéndola en todas partes por muy poco, y no pudiéndose librar de esa pésima costumbre, las viejas inmediatamente se agarran a la alcahuetería y a los hechizos, unidos estrechamente a ella, los pequeños hijos de los pobres se educan malísimamente, ellos mismos, echados con sus hijos ante los templos o pidiendo de aquí para allá, ni participan en las ceremonias, ni escuchan la predicación ni se sabe bajo qué preceptos o costumbres viven, qué piensan de la fe y de las costumbres. Hasta tal punto se ha desvanecido la organización eclesiástica que nada se administra gratis: detestan la palabra vender, pero con seguridad obligan a contar; por su parte, el obispo o el sacerdote piensan que unas ovejas tan peladas no pertenecen a su redil y a su pastizaje.

Así no hay nadie que vea a aquellos mendigos confesarse ni comulgar con los demás en la mesa del Señor, y, puesto que no oyen nunca a nadie que les enseñe, es necesario que juzguen sobre las cosas de manera muy viciada, que sean de costumbres muy disolutas y que, si casualmente de alguna forma llegan a las riquezas, sean intolerables por su educación vergonzosa e indecente, de donde surgen los vicios que hace poco he reseñado, que han de ser imputados no tanto a ellos como también a veces a los magistrados, que no miran por la ciudad de otra forma, no estableciendo normas rectas sobre la gobernación del pueblo al considerar que sólo están al frente de él para los litigios de dinero o para sentenciar los delitos, siendo así que es más conveniente que se dediquen a cómo hacer buenos ciudadanos que a cómo castigar o reprimir a los malos. ¡Cuánto menos, en efecto, necesarias serían las penas si se hubiese atendido antes con rectitud a aquello!» ${ }^{101}$.

A nuestro juicio, el potencial crítico de Vives no tiene discusión, pues no se arredra ni ante el poder civil, ni ante el eclesiástico. Su lacerante ironía expresa, magistralmente, su convicción de que todos tenemos una responsabilidad solidaria frente a un tema social y humanamente tan grave como es el de la pobreza.

Ya en el terreno de las actuaciones concretas, Vives propone un censo de pobres, donde se recoja un informe sobre la peculiar situación de cada uno de ellos. Se trata de una medida con la que se pretende conocer las circunstancias concretas personales de cada cual, y a un tiempo, evitar el posible fraude ${ }^{102}$. Por otra parte, Vives insistirá en que el pobre ha de recibir todo lo que necesite, pero también habrá de contribuir con su trabajo, en la mendida en que se lo permita su salud y edad, a la comunidad. Nadie debe beneficiarse de una prestación y permanecer ocioso, dirá, pues Vives concibe siempre a la sociedad como un cuerpo, donde toda parte tiene alguna función, por pequeña que sea. La comunidad es concebida como un sistema de cooperación, como una familia, en la que lógicamente ha de participar también el que recibe asistencia de las instituciones públicas ${ }^{103}$. Con esta medida, consideramos que Vives no sólo pretende evitar la tan cuestionada ociosidad, sino también restablecer la dignidad del que la perdió a causa de la pobreza, y evitar su rechazo social.

\footnotetext{
101 Ibídem, Libro II, capítulo I.

102 Cfr. Ibídem, Libro II, capítulo II.

103 Cfr. Ibídem, Libro II, capítulo III.
} 
En donde, sin embargo, se muestra la mayor firmeza vivista, y para evitar que, como solemos decir, acaben pagando justos por pecadores, es en el caso de que la causa de la pobreza tenga como motivo la pereza, y no las circunstancias ajenas a la voluntad del pobre. Sólo en tal situación, éste debería ser devuelto a su ciudad de origen, porque piensa Vives que, si la pereza fuera la causa por la que se practica la mendacidad, entre vecinos y parientes siempre resultará más vergonzoso mostrarse perezoso, por lo que retornar a sus pueblos o ciudades les ayudará a salir de tal estado. Otra cosa bien distinta sucede si el que llega a la ciudad, demandando ayuda, procede de una aldea muy pequeña, donde se entiende que carece de oportunidades, o simplemente, huye de la guerra. En tales circunstancias, el planteamiento es bien distinto, y la acogida ha de ser plena:

«Pero, si son de aldeas o pequeñas poblaciones azotadas por la guerra, entonces hay que tomar en consideración lo que enseña Pablo, esto es, que entre los bautizados en la sangre de Cristo no hay ya griego ni bárbaro, ni francés ni flamenco, sino una nueva criatura: han de ser tenidos por nativos» ${ }^{104}$.

La actitud de Vives es inclusiva. El Consejo debe estudiar caso por caso, y también el de aquellos que padecen ceguera o alguna enfermedad nerviosa, pues el trabajo para la comunidad les ayudará a mejor sobrellevar dicha enfermedad ${ }^{105}$. Y especial atención merecen los niños. Y particularmente los niños expósitos ${ }^{106}$, que han de ser alimentados en el hospicio, y han de recibir formación en la escuela pública, pues la educación es un pilar básico de la sociedad:

«Presidan esta escuela hombres en la medida de lo posible de educación cuidada y esmerada, que traspasen sus costumbres a esa escuela tosca, pues a los hijos de los pobres el mayor peligro les viene de una educación baja, sórdida e impropia de ciudadanos; no ahorren gastos los magistrados en la búsqueda de tales maestros, pues proporcionarán con un gasto pequeño un gran servicio a la ciudad que presiden» ${ }^{107}$.

No obstante todo lo anterior, el pensamiento de Vives tendría un carácter reformista, pues pretende solventar el problema de la pobreza haciendo cambios cualitativos en la estructura social, sin querer transformarla radicalmente ${ }^{108}$. En tal contexto, al ser la Iglesia portadora de grandes bienes, en buena medida la solución para socorrer a los pobres estaría también en su mano. Pero no se le puede obligar a hacerlo, y la violencia tampoco tiene para Vives justificación alguna:

«Éstos, los abades y las demás jerarquías eclesiásticas, si quisieran, podrían socorrer a la mayor parte de los necesitados con la gran cantidad de sus rentas: si no quieren, Cristo los castigará. Hay que evitar siempre la perturbación y la discordia entre ciudadanos, que son un mal mayor que retener el dinero de los pobres, pues ningún dinero, por cuantioso que sea, debe ser tan importante para los cristianos que por su causa se tomen las armas. Hay que servir por completo a la tranquilidad pública, que prescribió Cristo y Pablo siguiendo al maestro; (...)»109.

\footnotetext{
104 Idem.

105 Cfr. Ibídem, Libro II, capítulo III.

106 Cfr. Ibídem, Libro II, capítulo IV.

107 Idem.

108 Cfr. Moreno Gallego, op. cit., 452-453.

109 Vives, $D s p$, Libro II, capítulo VI.
} 
Ello no obsta para que, siempre que considera oportuno, el gran humanista valenciano se muestre muy crítico con la posición a la que, en su historia, ha llegado la Iglesia, como también en lo relativo a su amor por la pompa y el boato, que se aparta del buen sentido y hacer de los primeros cristianos ${ }^{110}$.

Por otra parte, prosiguiendo con las medidas concretas a tomar, Vives cree que, en buena medida, bastaría con gestionar eficiente y honradamente los hospitales, y las rentas producidas por el trabajo de todos, para afrontar el problema de la pobreza, evitando, además, la corrupción en la gestión, como se dice que parece que ha sucedido en España, donde los gestores benefician a familiares y amigos, en lugar de a los pobres ${ }^{111}$.

Y como apuntábamos más arriba, Vives contempla las más diversas causas por las que un hombre puede ser arrastrado a la condición de pobre, entre las que, y de no poca importancia, estaría nuestra exposición a la fortuna. Tal sobrevenida circunstancia exigirá, por tanto, responder ante ella, máxime cuando junto a la pobreza convive una insensible opulencia, difícil de digerir, ni cristiana, ni humanamente hablando:

«No ha de socorrerse sólo a los pobres que carecen de las cosas necesarias para la vida todos los días, sino también a aquellos sobre los que sobreviene alguna desgracia súbita, como cautiverio en la guerra, prisión por deudas, incendio, naufragio, inundación, muchas clases de enfermedades, finalmente innumerables desgracias fortuitas que afligen a familias honradas; a todo esto se añaden las muchachas pobres, a las que muchas veces la miseria empuja a hacer mal uso de su pudor. En efecto, no se puede soportar que en una ciudad, no digo ya cristiana sino ni siquiera pagana con tal de que se viva según costumbres humanas, por cincuenta o cien florines se ponga en peligro la honestidad de una doncella, la salud y la vida de un hombre honrado, que un hombre se vea obligado a abandonar a su esposa y a sus hijos pequeños, mientras otros sobreabundan en riquezas hasta tal

110 «Ciertamente en otros tiempos, como todavía hirviese la sangre de Cristo, todos arrojaban sus riquezas a los pies de los apóstoles para que ellos mismos las distribuyesen según las necesidades de cada uno; después los apóstoles rechazaron este cuidado como indigno de ellos, puesto que convenía más que predicasen y enseñasen el Evangelio que ocuparse en pedir y repartir el dinero, y así esta función se confió a los diáconos; y ni siquiera éstos la retuvieron mucho tiempo: tan grande era el afán por enseñar, por elevar la religión, por apresurarse a los bienes eternos por medio de una hermosa muerte; por tanto, seglares cristianos proporcionaban a los pobres del dinero recolectado lo que necesitaba cada uno. Sin embargo, al aumentar el pueblo cristiano y al ser admitidos muchos no demasiado honrados, algunos empezaron a administrar aquella actividad con mala fe; los obispos y los sacerdotes por su amor hacia los pobres recibieron de nuevo bajo su cuidado las riquezas reunidas para socorrer a los necesitados, pues en aquel tiempo todo se confiaba a los obispos, hombres de una rectitud y de una lealtad experimentada y reconocidas, como lo cuenta Juan Crisóstomo en cierto pasaje. Pero después se enfrió más y más el ardor de la sangre de Cristo, y el Espíritu del Señor se comunicó a muy pocos; la Iglesia empezó a imitar al mundo y a competir con él en pompa, suntuosidad y lujo; ya Jerónimo se queja de que los prefectos de las provincias comen en los monasterios más espléndidamente que en palacio; para tales gastos se necesitaba gran cantidad de dinero: de esta forma los obispos y sacerdotes convirtieron en su patrimonio y en su hacienda lo que había sido sólo de los pobres; ojalá que les tocase el Espíritu de Dios y llevasen a su memoria de dónde lo tienen, por quiénes les fue dado, con qué intención, y recordasen que son poderosos con los recursos de los débiles». Idem.

111 Cfr. idem. 
punto que malgastan unos miles de áureos en un sepulcro, en un palacio, en un edificio inútil, en un banquete o en un espectáculo público» ${ }^{112}$.

Sabe muy bien Vives que, a pesar de la belleza moral de su propuesta, siempre habrá críticos que pretendan refutarla, cuestionando las costumbres y placeres a las que, a veces, se entregan los pobres ${ }^{113}$, o simplemente alegando que, como Cristo dijo, "siempre habrá pobres», para lo cual tiene una sencilla respuesta: siempre los habrá, en efecto, y Cristo lo sabía perfectamente, pues conocía muy bien nuestro corazón egoísta, pero ello no nos exime de hacer todo lo que esté en nuestra mano para tratar de reducir la pobreza, o minimizarla en sus efectos:

«No predijo Cristo que los pobres estarían siempre con nosotros porque él mismo lo quisiese, ni que llegarían los escándalos porque le agradasen, puesto que nada nos recomendó con más diligencia que el auxilio de los pobres, y maldice a aquel que ofreció motivos para el escándalo. Pero porque conocía nuestra debilidad, por la que nos precipitamos a la pobreza, y también nuestra maldad, por la que no levantamos enseguida al caído, sino que permitimos que quede tirado y se pudra, por eso predice que siempre tendremos pobres; (...)Así, pues, con estas predicciones no nos manda Cristo que actuemos, sino que ve que obraremos así; de esta forma, estos proyectos nuestros no hacen desaparecer a los pobres sino que los alivian, no impiden que alguien sea pobre, sino que lo sea por mucho tiempo al extenderle inmediatamente la mano para que se levante.

Quisiera por completo que pudiéramos conseguir que no hubiese ningún pobre en esta ciudad; no temería el peligro de que se pensase que Cristo había dicho algo falso: habría muchísimos en otras ciudades. Y no sólo son pobres los que carecen de dinero, sino cualesquiera privados de fuerzas corporales, de salud, de inteligencia o de juicio, como explicamos al principio de esta obra. Añado que no menos ha de ser llamado pobre, incluso de dinero, aquel a quien ya en el hospital, ya en su humilde casa se le proporciona un digno alimento, no conseguido con su actividad o trabajo sino debido por completo a la beneficencia ajena» ${ }^{114}$.

Como estamos teniendo ocasión de comprobar, las razones derivadas de la coherencia cristiana van trenzándose con aquellas otras razones humanitarias, y de justicia natural, que convierten la responsabilidad para con el pobre en un imperativo moral inexcusable para todos:

«En verdad ¿quiénes obran de forma más inhumana los que quieren que los pobres se pudran en sus inmundicias, suciedad, vicios, ignominias, descaro, desvergüenza, ignorancia, locura, desgracia y miseria, o los que descubran un camino por el que los lleven, liberados de aquello, a una vida más civilizada, más pura y más culta con una ganancia tan grande para tantos hombres inútiles y perdidos? ${ }^{115}$.

Porque, al final, y engendrada por la soberbia, es la avaricia del hombre el mayor obstáculo con el que se encuentra la pobreza ${ }^{116}$. Una avaricia, dirá Vives, que no sólo es vergonzosa, sino detestable, porque si malo es quitar algo a un rico, cuánto peor no será robarle a los pobres y privarles de aquello que, por razones humanitarias

$112 \quad$ Ibídem, Libro II, capítulo VII.

113 Cfr. Ibídem, Libro II, capítulo VIII.

114 Ibídem, Libro II, capítulo VIII.

115 Idem.

116 Cfr. Ibídem, Libro I, capítulo VII. 
y cristianas, se les debe ${ }^{117}$. Y Vives, que no deja nigún frente sin cubrir, no sólo insistirá en los deberes, sino en los frutos, tanto materiales como espirituales, que un cambio de actitud nos depararía ${ }^{118}$. Por lo que a las razones de la charitas, y de la humanitas, vendrían a sumarse las de la prudentia y la moral, pues los beneficios que se obtendrían de este cambio de actitud moral no sólo alcanzarían a la paz social, sino también a la órbita espiritual, y no sólo de quien es socorrido, sino también de quien socorre ${ }^{119}$. Tal es el Vives, humanista y cristiano, que se rebela ante la pobreza, que exige responsabilidad ante la misma, y que nos exhorta con todo tipo de razones para poner fin a tan lacerante injusticia, brindándonos una extraordinaria ocasión para, a su vez, renovarnos moralmente a nosotros mismos.

Que Vives dedicó su obra, en la Brujas del XVI, a los burgomaestres Jozef de Baenst y Jan van Themseke, es un hecho. Pero que sus palabras puedan ser hoy una fuente de inspiración y de reflexión sobre nuestra responsabilidad para con los más necesitados, queda fuera de toda duda, en un mundo donde la pobreza, y el olvido en el que tratan de sobrevivir los pobres del mundo, clama al cielo, y nos interpela a nosotros, hombres del siglo XXI, si no para erradicarla definitivamente, pues «siempre habrá pobres», ya que siempre habrá situaciones de injusticia que remediar, sí al menos, para cambiar nuestra actitud frente a un problema que ni como cristianos, ni como hombres, puede sernos indiferente. Y el propio Vives sabía que, aunque los contextos puedan variar, y haya que desarrollar medidas concretas distintas, o arbitrar otras nuevas, los principios y las reglas fundamentales, las razones religiosas y humanitarias, y también prudenciales, que las avalan, conservarán plenamente su vigencia, por lo que en un tema de justicia y alcance como éste hemos de permanecer siempre unidos:

«Ciertamente estas son las cosas que me parece que hay que hacer en la situación presente; quizás no convenga mantenerlas todas, tal como han sido dispuestas por mí, en todas las ciudades y en todo momento; que lo vean las personas prudentes en cada población, y que miren por el bien de su ciudad con afecto hacia su tierra; en realidad he prefijado el mismo fin, el mismo proyecto y la misma meta, que creo que serán convenientes y oportunos siempre y para todo lugar; pero, si no conviene que se hagan todas las cosas al mismo tiempo, porque la costumbre aceptada se opondrá quizás a la innovación, será posible servirse de alguna maña e introducir al principio las más fáciles y después, poco a poco, las que se consideran más difíciles. Nada hay tan bien establecido como lo que es adecuado en todo tiempo y lugar. Por eso intervendrá la prudencia a fin de que mire por cada una de las actividades. Sobre todo evítese la división, cruel plaga de las ciudades» ${ }^{120}$.

En suma, Vives, cristiano y humanista, crítico de la avaricia y de la soberbia humanas, defensor de los pobres, nos interpela con todo tipo de razones (prudenciales, morales, humanitarias y religiosas) para que no haya resquicio alguno por el que podamos disculpar nuestra insensibilidad ante la pobreza, a la vez

117 Cfr. Idem.

118 Cfr. Ibídem, Libro II, capítulo X.

119 Cfr. Ibídem, Libro I, capítulo IV y VIII; y también todas las ventajas de obrar bien en Libro II, capítulo X.

120 Ibídem, Libro II, capítulo VII. 
que nos exhorta para que hagamos nuestra la responsabildad ante ella, y hagamos frente común, tanto en el plano personal, moral y religioso, como institucional, para erradicarla o combatirla, integralmente, en lo material y en lo espiritual. Y al hacerlo, no sólo habremos contribuido a hacer frente al sufrimiento injusto de tantos y tantos seres y vidas humanas, lo cual ya es muchísimo, sino que, al mismo tiempo, habremos contribuido, substancialmente, a la mejora de nuestro mundo, así como de todos y cada uno de nosotros, fieles a nuestra común humanidad y a los principios del humanismo integral cristiano, que Juan Luis Vives supo tan ejemplarmente defender, con su vida y con su obra.

Universidad de Sevilla

José Manuel Panea Márquez

jmpanea@us.es

[Artículo aprobado para publicación en diciembre de 2016] 